DOI: https://doi.org/10.34069/AI/2021.47.11.27

How to Cite:

Holubenko, N. (2021). Specific features of intersemiotic translation of symbols from the perspective of conceptual and semiotic paradigm. Amazonia Investiga, 10(47), 263-270. https://doi.org/10.34069/AI/2021.47.11.27

\title{
Specific features of intersemiotic translation of symbols from the perspective of conceptual and semiotic paradigm
}

\section{Características específicas de la traducción intersemiótica de símbolos desde la perspectiva del paradigma conceptual y semiótico}

Received: September 12, 2021
Accepted: October 30, 2021

Written by:

Natalia Holubenko ${ }^{112}$

https://orcid.org/0000-0002-4850-721X

\begin{abstract}
The text of the novel "Inferno" written by Dan Brown and its film adaptation, provide the material for the analysis of symbols and their importance in both art forms. This analysis, which rests on the thesis of the conceptual nature of symbols in any literary text, is made in conceptual and semantic fields, and the concepts denoted by the analyzed symbols are pointed out. Given that the text of the source novel is abundant in symbols of various degrees of textual importance, not all of them were subject of research in this paper. The basic symbol of the source text, the Inferno, was singled out, as well as a number of symbols embodied by novel and film personages. In the research, frequent techniques of intersemiotic translations were analyzed as concerns their role in symbol rendering: omission, typical of the studied case of intersemiotic translation, which can be combined with the technique of addition. In the latter case, the degree of expressive force of the symbol can be considerably altered. The greatest shift in the degree of importance of a symbol is named 'symbol transformation', it is observed when symbols (in the given case, symbolic personages of the source text) lose their expressive force and the features of a symbol, i.e., in the process of intersemiotic translation these symbols are lost. The suggested model of analysis can be applied in other cases of intersemiotic translation, and other techniques, together with their combinations, can be found.
\end{abstract}

\section{Resumen}

El texto de la novela "Inferno" escrito por Dan Brown y su adaptación cinematográfica, proporcionan el material para el análisis de los símbolos y su importancia en ambas formas de arte. Este análisis, que se apoya en la tesis de la naturaleza conceptual de los símbolos en cualquier texto literario, se realiza en campos conceptuales y semánticos, y se señalan los conceptos que denotan los símbolos analizados. Dado que el texto de la novela fuente es abundante en símbolos de diversos grados de importancia textual, no todos ellos fueron objeto de investigación en este trabajo. Se ha destacado el símbolo básico del texto fuente, el Infierno, así como una serie de símbolos encarnados por personajes de la novela y la película. En la investigación se analizaron técnicas frecuentes de traducción intersemiótica en cuanto a su papel en la representación de símbolos: la omisión, típica del caso estudiado de traducción intersemiótica, que puede combinarse con la técnica de la adición. En este último caso, el grado de fuerza expresiva del símbolo puede alterarse considerablemente. El mayor cambio en el grado de importancia de un símbolo se denomina "transformación del símbolo", se observa cuando los símbolos (en el caso dado, los personajes simbólicos del texto fuente) pierden su fuerza expresiva y las características de un símbolo, es decir, en el proceso de traducción intersemiótica estos símbolos se pierden. El modelo de análisis propuesto puede aplicarse en otros casos de traducción intersemiótica, y pueden encontrarse otras técnicas, junto con sus combinaciones.

\footnotetext{
${ }^{112} \mathrm{PhD}$ (Philology), Associate Professor, Korunets Department of English and German Philology and Translation, Kyiv National Linguistic University, Ukraine.
} 
Keywords: intersemiotic translation, source text, film adaptation, techniques of symbol rendering.

\section{Introduction}

This section is devoted to the history of intersemiotic translation as a research matter. Intersemiotic translation, according to $\mathrm{R}$. Jakobson, can in general terms be understood as the way of interpreting verbal signs in frames of the system of nonverbal signs (Jakobson, 1959). Currently this multimedia approach has received well-earned attention among linguists, as with the development of various media means literary pieces are turned into pieces of music, reproduced in the shape of screenplays, comics, musicals, cartoons etc. Distinguished by R. Jakobson still in late 70-ies of the last century, this multimedia approach to the study of works of art remained at the periphery of linguistic research, notwithstanding a centuries-old history of the synthesis of arts. These scholars introduced a deep reconsideration of the previous linguistic gains and viewed a text as a unified semiotic system. It was the papers of post modernists which gave a boost to the so-called world and consciousness 'textualization', as postmodernism was the first to have qualified world arrangement as a text (Gibbs, 2011). But true tenets for the approach can be found in the books by J. Lotman. The scholar claimed that producing new meanings is an essential function of any aesthetic text. Creating its own semiotic space where languages, organized hierarchically, interact every text as well is a "generator of sense" so it requires a dialogic interrelation with other texts so that it may function. J. Lotman claimed that the spectator himself is a "text" (Lotman, 2000). To cite one example, the interrelation between the film and the fictional text that serves as the basis of it, or the two-way feedback between the basic story and the accomplished film, may be regarded by means of constructing "model" readers or viewers, which are considered as text strategies that advance into action or cease their operating reciprocally.

Creatively developing these ideas, the authors of somewhat later period argue that intersemiotic translation represents a complex "form of action," which is a trans-cultural, fast-moving and functional event, appearing between the necessity of remaining authentic and the need to transform it into a well-understood text which may be accepted as some other form of art, rather than a simple transcodification (Koller, 1995), (Pym, 1992), for instance, a film. Referring to the fundamentals, most papers on intersemiotic
Palabras-clave: traducción intersemiótica, texto fuente, adaptación cinematográfica, técnicas de representación de símbolos.

translation use the famous Jakobson's three-part categorization of transformations occurring in film adaptations of literary texts, though the scholar himself chose the term 'transmutation': 1) intralingual translation or rewording, which stands for the interpretation of verbal signs through other signs in frames of of the same language; 2) interlingual translation or translation proper, i.e., interpreting verbal signs by the instrumentality of some other language; 3) intersemiotic translation or transmutation, seen as an interpretation of verbal signs through using nonverbal sign systems (Jakobson, 1959, p. 233).

Though quite widely used in the studies in the field in question, this Jakobson's division was reconsidered by U. Eco (2000), who argued that different kinds of translations are interpretations, in the first place, and suggested a new classification. It includes intrasystemic interpretation in the view of which intersemiotic translation can be nothing but adaptation: it inevitably changes a source text, explicating the unsaid or reinterpreting the images. U. Eco notes that in the transposition from a novel to a film you will always find a "transmutation of purport," because the verbal form of expression cannot be mapped one to one onto another, nonverbal artistic form (Eco, 2001). Admittedly, in studying any work of art, a great role belongs to the analysis of symbols in this or that particular art peace, as it is often because of symbols that the work of art is created. J. Lotman attributed the major importance to symbols in any belleslettres text, noting that they are 'the genes of the plot' (Lotman, 2000).

Given a piece of literary art, symbols can be seen as objects or references adding a more profound meaning to the story plot and enhancing a theme, as well as an idea or a character. On cultural interpretation level symbols have always been perceived as the result of culturally marked meanings of the word or phrase which embodies this symbol (Kuznyetsova, 2019; Langacker, 2010). It is impossible to underestimate the role of symbols in a work of art. According to R. Firth, an artist's creativity reveals the display of his insight, where symbolization may play an important, and even as much as a vital part. The symbols should be peculiar, individual, unique and special, with the mark of the power of the 


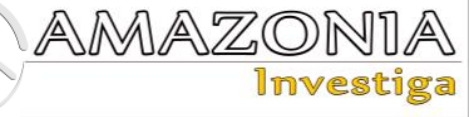

artist's imagination, if he wishes to arouse positive feelings in other people (Firth, 2013). Thus, the translation of a book's symbols onto a cinema discourse provides a considerable research interest, especially because in both art forms the imaginative force of the creators is a purely individual matter which can serve a characteristic of both creators' (i.e., the author's and the team of the film adaptation creators') style, attitude to the theme expressed and artistic maturity. So, the interrelation between the symbols in a literary text and its film adaptation provide a worthy field of study. The research material of this study is 1) the text of the novel "Inferno" by Dan Brown (Brown 2013). The objective of the research is 1) to identify the verbal and non-verbal methods of intersemiotic translation of the symbols applied in the work of literature into its film adaptation; 2) to analyze the semiotic means of translation of these images in the process of film adaptation with the view of semiotic and cognitive mechanism for interpreting such a multimodal text.

\section{Research methods}

This study was exercised with the use of the following research methods:

1) continuous sampling method, as concerns text and cinematographic elements which served to express and represent the symbols;

2) descriptive method, which allowed to systematize the obtained text and cinematographic data;

3) elements of cognitive, comparative and associative analyses enabling the study of possible equivalence in the process of intersemiotic translation of text symbols.

\section{Results \& discussion}

Grasping and comprehension of special features of translation of a piece of literature into a piece of cinematography, or of transition from a literary work into a feature motion picture provided the object of numerous investigations, both in literary and cinematographic areas (Wildfeuer \& Bateman, 2017; Matito, 2019). The use of numerous mechanisms of intersemiotic translation while rendering a belles-lettres novel text into a theatrical film is to both the linguists' and the cinematographers' advantage. For the former, they help grasp the many-level complex nature of translation, occurring to language means of a belles-lettres text, for the latter they serve as the means to upgrade their work. Notwithstanding the fact that there exist several attempts of the study of the transformation of a piece of literature into a film narration (Dusi, 2015; Lhermitte, 2005; Lukianova \& Ilchenko, 2019; Perdikaki, 2017), the analysis of transformations happening to the belles-lettres text in the process of adapting it into a film with its specific semiotics in view of the text's symbols can provide interesting information as concerns the interrelations between the two art forms (GradeSaver, 2021). The reason for this assumption is the very nature of symbols on a literary text: they attract a special reader's interest and thuswise turn him into an active participant of a text as a discourse component (All American). The text of "Inferno" is abundant in various symbols some having a plotcreating role, like the symbol of hell introduced in the title of the novel, others being rather subtle. However, the writer's imagination entangles them into a fascinating complex which serves to reveal his ideas. This study proceeds from the generally acknowledged principle that symbols are of concept nature, as their creation and anticipation is founded on complicated cognitive processes (Cunha, Martins, Cardoso \& Machado, 2017; Fauconnier \& Turner, 1998). The symbol of hell in Dante's vision or of Inferno is undoubtedly the central one in the analyzed literary text (Inferno. The movie database, 2016). The very first introduction of Inferno is detailed, picturesque and expressive:

\section{A veiled woman}

Robert Langdon gazed at her across a river whose churning waters ran red with blood. On the far bank, the woman stood facing him, motionless, solemn, her face hidden by a shroud. In her hand she gripped a blue tainia cloth, which she now raised in honor of the sea of corpses at her feet. The smell of death hung everywhere.

Seek, the woman whispered. And ye shall find.

Langdon heard the words as if she had spoken them inside his head. "Who are you?" he called out, but his voice made no sound.

Time grows short, she whispered. Seek and find.

Langdon took a step toward the river, but he could see the waters were bloodred and too deep to traverse. When Langdon raised his eyes again to the veiled woman, the bodies at her feet had multiplied. There were hundreds of them now, maybe thousands, some still alive, writhing in agony, dying unthinkable deaths ... consumed by fire, buried in feces, devouring one another. He could hear the mournful cries of human suffering 
echoing across the water (Brown, 2013, p. 16). The author uses here quite a number of powerful expressive means: the cluster of an epithet and a metaphor 'churning waters ran red with blood', metaphors 'the sea of corpses', 'consumed by fire', 'buried in feces', 'devouring one another', epithets 'the woman stood facing him, motionless, solemn', 'the mournful cries of human suffering', a hyperbole 'the bodies at her feet had multiplied. There were hundreds of them now, maybe thousands'.

All of them, together with the construction of the fragment, create a vivid, strikingly frightening picture of the terrible Inferno and serve as linguistic means to verbalize the concept HELL. To reproduce this fragment in the film adaptation, the film creators use nonverbal cinematographic means of the visual type: everything is shown, staged with the use of numerous visual effects, like shooting from height, using close-ups, shooting with a specifically moving camera, etc. If compared to the text description, this film episode retains a number of important details, simultaneously lacking some others and introducing a new perspective: Professor Langton doesn't simply observe a disgusting and frightening scene, he finds himself right in it, walking past the dying bodies and trying to escape. So, in the film adaptation specific cinematographic means of expressing the concept HELL are used. Here we investigate the problem of the peculiarity of each artistic device that rests on the fundamental difference in the ways of their representing the so-called real world (Dusi, 2015) and in in the distinct difference in the degree and areas of indeterminacy while representing the same part of a story (Chatman, 1978; Jaubert, 1990). N. Dusi rightfully notes that referring to cinematic elements, one should remember of their not only being "staged" commencing from a more profound level of signification, but of their being "framed" (shot, or, to put it more precisely, modified into a discourse from the targeted declarative point of view) and then "sequenced" (in other words, remade in the syntagmatics of editing and in the manipulator post-production capacities) as well. At every textual stage the film can build ambiguity and indefinability (Dusi, 2015, p. 89-90).

Another speculation concerns the repeatability of the Inferno symbol in the original text and its film adaptation. In the text, reference to the notion of Hell can be found more than 20 times, in the majority of cases the notion being verbalized either through a colorful description, or through the use of the contextually determined historicism 'Inferno': A familiar vision materialized - the statuesque, veiled woman with the amulet and silver hair in ringlets. As before, she was on the banks of a bloodred river and surrounded by writhing bodies. She spoke to Langdon, her voice pleading. Seek and ye shall find! (Brown, 2013, p. 23).

The explicit use of the name 'Inferno' is noted at the beginning of the novel and in the concluding chapters. In some cases, both nominations, 'Inferno" and 'hell' which express the concept HELL, can be found within the same close context, for instance: Langdon again felt troubled to know that the final canto of Dante's Inferno ended in a nearly identical scene: After a long descent through the underworld, Dante and Virgil reach the lowest point of hell (Brown 2013, p. 309).In the film, however, 17 references to the same notions are observed in which the nomination 'hell' is used, together with the visual image, and the nomination 'Dante's Inferno" was marked in 3 instances. Thus wise, it seems clear that the creators of the film chose to use a simpler, more understandable verbal nomination, combined with the visual means of expressiveness to introduce one of the major symbols of the film and one of its major concepts. It can be seen in the above text examples that the realization of the symbol Inferno is combined with another, less prominent but expressive symbol of a silver-haired lady who can be considered a guardian of normal life against hell. For instance:Again Langdon saw the silverhaired woman calling out to him from across the river (Brown, 2013, p. 98).

In terms of Ch. Pierce's semiotic paradigm, this symbol, being not dynamic but frequently used, should be treated as a sign-symbol, i.e., the signifier and the signified bear no resemblance; how they associate with each other should be culturally learned (Peirce, 2000). The reference to Ch. Pierce's ideas meet one of the basic thesis of this study that the creation of symbols rests on cognitive operations, as the philosopher thought that people cogitate only by means of signs (Peirce, 1931/58) which "take the form of words, sounds, images, flavors and odors, acts or objects" (Chandler, 2017) only when interpreted as 'signifying' something, i.e. invested with a separate meaning (Peirce, 1931/58). Such way of interpreting signs is unconscious as people relate them to familiar systems of conventions.

As for the fewer cases of the use of the symbol Inferno in the film adaptation, here we can observe the so-called omission of the translation of the symbol, which is often observed in 


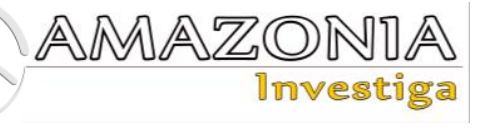

intersemiotic translations. In case of the adaptation of the novel "Inferno", this observation is not meant to criticize. The matter is that with film adaptations, the creators are strictly limited by the film timing, while the reader's perception of the literary source is not limited in time at all. Ch. Keane, a famous American screenwriter, remarked that an ideal screenplay should contain from one hundred to one hundred and twenty pages, with one page corresponding to approximately one minute of the film (Keane, 2009, p. 71). Considering the fact that the text of the analyzed novel numbers about 375 pages, and the duration of the film adaptation is about 150 minutes, certain omissions are inevitable.

The sign-symbol of a woman with ringlets of silver hair develops in a source text into one of the characters, a living person, Elizabeth Sinskey, heading the World Health Organization who actually made Robert Langton fly to Florence. Due to his amnesia, he couldn't identify this image from his visions at first, though when they met their cooperation was quite fruitful. However, in the film adaptation considerable changes are observed: there is no silver hair, but the ash-grey cloth covering the lady's head together with her face, so that it is difficult to decipher whether this lady from Langston's visions is really Elizabeth Sinskey. Besides, in the film adaptation this character looks different: she has dark straight hair and is noticeably younger than in the source text. Moreover, the relationship between her and Langton is substantially reconceived: they happen to have known each other for a long time and have experienced rather a dramatic love affair when much younger. From this angle, this film personage is much more vivid and understandable, but at the same time it is less symbolic. Thus, in the analyzed instance such techniques of intersemiotic translation are observed as omission on the one hand, and addition on the other, because the team of filmmakers can add any kind of information they find necessary (Lukianova \& Ilchenko, 2019). It can be stated that the character of Elizabeth Sinskey in the film adaptation is recast, and this alternation is accompanied by the omission of its symbolic importance. Speculating on such changes in film adaptations, we can't but agree with Lhermitte (2005), who wrote: "By taking literary works to the screen, film adaptations widen the scope of their readership, offering them greater visibility. Metaphors are changed into more comprehensible images; idiomatic expressions are replaced by explicit phrases and cultural rites are explained or transposed in an effort to make them more accessible to the reader. In the process, adaptors cannot ignore the cultural background of the target culture and must "negotiate" the interaction of the audience with the source text" (p. 14).

Another symbol, though of a subtler nature, is introduced by the personage of Sienna Brooks, a former child prodigy who possesses a surprising number of various skills. In the source text, the symbolism of this image can be seen already in the first descriptions of this young woman, who looks like an angel, a symbol of help and good intentions, a modern guardian angel: Tall and lissome, Dr. Brooks moved with the assertive gait of an athlete. Even in shapeless scrubs, she had a willowy elegance about her. Despite the absence of any makeup that Langdon could see, her complexion appeared unusual smooth, the only blemish a tiny beauty mark just above her lips. Her eyes, though a gentle brown, seemed unusually penetrating, as if they had witnessed a profundity of experience rarely encountered by a person her age (Brown, 2013, p. 17). Sienna was transformed - a natural beauty - having changed into formfitting jeans and a cream-colored sweater, both of which complemented her lithe figure. Her hair was still pulled back in a ponytail, and without the authoritative air of medical scrubs, she seemed more vulnerable somehow (Brown, 2013, p. 44).

To make the image expressive and positively anticipated, the writer uses quite a number of epithets: 'a willowy elegance', 'her complexion appeared unusually smooth', 'a tiny beauty mark just above her lips', 'gentle brown eyes', 'unusually penetrating', 'a natural beauty', 'her lithe figure'. Such descriptions undoubtedly serve to create a somewhat idealized image, easily developed into a symbol on the basis of stereotypical ideas of what a guardian angel should be like. So, it can be said that this symbol is the presentation of a concept GUARDIAN ANGEL. The meaning of this symbol is revealed on the surface level of the text of a novel when it is expressed by the name of this concept, for instance:

Dr. Brooks leaned over him, hovering like an angel (Brown, 2013, p. 22).

However, Dan Brown himself dispels this somewhat idealized symbol he has created himself, structuring a contextual hint as to the forth-coming events in the novel:

Sienna walked tiredly down the hall to the apartment's modest bedroom. Retrieving a pair 
of blue jeans and a sweater from the dresser, she carried them into her bathroom. Locking her eyes with her own reflection in the mirror, she reached up, grabbed a clutch of her thick blond ponytail, and pulled down hard, sliding the wig from her bald scalp. A hairless thirty-two-yearold woman stared back at her from the mirror (Brown, 2013, p. 41).

In this fragment the author of the source text removes the stereotyped attributes of a young angel-like creature: Sienna's bald head shows that the woman has a lot to conceal, and she is not as young as she looked at the beginning of the novel. Notably, in the film adaptation Sienna Brooks is very good-looking, but rather in a sexappealing way, her hair is brown, but not blond, and the fact of her wearing a wig is totally absent. The reference to her being a prodigy child is very scarce. Thus, the absence of important details and parts of the plot related to this personage deprives it of symbolic characteristics, and the very concept of this symbol becomes vague and uncertain. The lowering of symbolism degree is also determined by considerable alterations of the film story as compared to the source text: in the book the searched-for virus container performs its role and an enormous number of people get infected without feeling anything; at that Sienna takes an active part in facilitating the process of putting the dangerous virus container into action. When Robert Langton, Dr. Sinskey and her team lose the fight about the virus, Sienna departs to receive her legitimate judgment. While in the film adaptation Sienna actively fights and perishes, not having survived the explosion, which was absent in the source text. This character is greatly altered in the film adaptation; there is nothing symbolic about her, as she has the characteristic of a well-prepared terrorist. So, it can be stated that the symbol of the source text is transformed to its non-existence, and this technique in the intersemiotic translation can be named 'transformation'.

One more symbol which undergoes transformation is another character, Bertrand Zobrist, a dark genius who invented the dangerous virus. In the source text this personage is a symbol of evil, which is often in the focus of the story, though by the time of the novel's temporal start he has been dead for five days. This personage is the embodiment of the concept EVIL in the text of the novel. The transformation of this symbol of evil is seen even in the difference of physical appearance between the novel personage and the film adaptation character. This is how Zobrist is described in the book:
The visitor, a notable figure in his field, was forty-six, clean-cut, and exceptionally tall, with piercing green eyes...

The disheveled man who arrived on the yacht was barely recognizable as the steady, clean-cut person with whom the provost had done business the year before. He had a wild look in his oncesharp green eyes. (Brown, 2013, p. 67).

A towering, elegant form takes the stage. He is tall ... so very tall ... with vibrant green eyes that seem to hold all the mysteries of the world in their depths (Brown, 2013, p. 236).

These descriptions especially specify the character's expressive green eyes and his remarkable height and elegance. However, in the film adaptation Zobrist is a person of normal height, well-built but not especially elegant, with reddish-brown hair and dark-brown eyes. Besides, his love story with Sienna is cut short to occupy just about two minutes of the screentime. And it wasn't Sienna Brooks that saw him jump down from the tower, but a WHO police agent. Generally, this film adaptation personage receives a very short screen time. It can be stated that the symbol of evil in the source text is the subject of such transformations in the film version that it loses all features of a symbol. In other words, in the process of intersemiotic translation this symbol vanishes from the film adaptation and doesn't exist there. Notwithstanding the fact that the issues if intersemiotic translation were studied in the papers of such linguists as N. Dusi, C. Lhermitte, T. Lukianova and F. Ilchenko, K. Perdikaki, new research in this field can be considered welcome, as both writers' and cinematographers' artistic methods possess unique peculiarities, and thus provide material for investigation. The aspect of symbols presentation in both art forms have not been the subject of research yet, so from this angle this paper deserves attention.

\section{Conclusions}

This paper is aimed at the study of specific features of intersemiotic translation of symbols in the novel "Inferno" by Dan Brown and its film adaptation. The symbols of a literary text are understood as wholly individual creations which are connected with certain concepts they express. The study showed that in the process of intersemiotic translation not all symbols of the source text are retained in the film adaptation, which is mostly determined by the cinematographers' vision of the plot, but also by the discordance in time allowed for the 


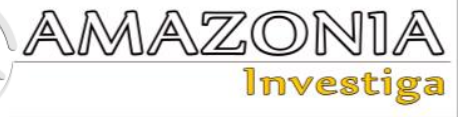

perception of the novel and of its film adaptation. This process includes a number of techniques typical of intersemiotic translation, and namely, the techniques of omission and addition, which can be combined, as concerns rendering of one and the same symbol. In the course of these techniques' application, the sense of a symbol can change, and consequently, the degree of its symbolic importance can grow or decline. During the research the cases were noted when a symbol (mostly, a personage, possessing a symbolic role in the source text) undergoes considerable alterations in the process of intersemiotic translation to the degree of the loss of symbolic importance. Such phenomena received the name of symbol transformations. These transformations may vary in their degree; in the analyzed film adaptation two symbolic novel personages lose their symbolic importance, and hence, such symbols are lost. The perspective of further research is seen in studying other cases of intersemiotic translation of literary text into film adaptations from the perspective of image-creating and symbol-creating means and techniques.

Conflict of Interest: The author has no conflict of interest to declare.

Grant Support: The author declared that this study has received no financial support.

\section{Bibliographic references}

Brown, D. (2013). Inferno: (Robert Langdon Book 4). London, England: Bantam Press.

Chandler, D. (2017). Semiotics for Beginners. Retrieved July 14, 2021, from Visualmemory.co.uk website: http://visualmemory.co.uk/daniel/

Chatman, S. (1978). Story and discourse: Narrative structure in fiction and film. Ithaca: Cornell University Press

Cunha, J. M., Martins, P., Cardoso, A., \& Machado, P. (2017). Generation of conceptrepresentative symbols. Cornell University. Retrieved from http://arxiv.org/abs/1707.09432

Dusi, N. (2015). Intersemiotic translation: Theories, analysis. Semiotica, 2015(206), 181-205. doi: $10.1515 /$ sem-2015-0018

Eco, U. (2000). A theory of semiotics. Bloomsberry: Indiana University Press.

Eco,U.(2001). Interpretation and Overinterpretation. Cambridge: Cambridge University Press.

Fauconnier, G. \& Turner, M. (1998). Conceptual integration networks. Cognitive science,
22(2),

133-187.

doi:

10.1207/s15516709cog2202_1

Firth, R. (2013). Symbols: Public and Private. London, England: Routledge

Gibbs, D. (2011). Arrendale library: Literary research guide. Glossary of literary terms. Retrieved from https://library.piedmont.edu/c.php?g=52135 $0 \& \mathrm{p}=3564521$

GradeSaver. (2021). Inferno symbols, allegory and motifs. Retrieved from https://www.gradesaver.com/inferno/studyguide/symbols-allegory-motifs

Jacobson, R. (1959). On Linguistic Aspects of Translation. On Translation in R. A. Brower (Ed.). The translation studies reader, 233-239.

Jaubert, J.-C. (1990). André Gaudreault From literary to filmic, narrative system, Preface by Paul Ricoeur, Lea presses of Laval University - Klinckieck meridians, 1988. Canadian Journal of Film Studies, 1(1), 89-92. doi: 10.3138/cjfs.1.1.89

Keane, C. (2009). How to write a selling screenplay. Broadway Books

Koller, W. (1995). The concept of equivalence and the object of translation Studies1. Target, 7(2), 191-222. doi:10.1075/target.7.2.02kol

Kuznyetsova, G.V. (2019). Implicit Speech Acts in Terms of Cognitive and Pragmatic Approach. Science Journal of Lutsk State University. Linguistics. Retrieved July 14, 2021, from Edu.ua website: http://eprints.zu.edu.ua/23967/1/Implicit\%20 Speech\%20Acts.pdf

Langacker, R. W. (2010). Concept, image, and symbol: The cognitive basis of grammar. Berlin, Germany: De Gruyter Mouton.

Lhermitte, C. (2005). A Jakobsonian Approach to Film Adaptations of Hugo's Les Misérables. Nebula, 2.1. Retrieved July 14, 2021, from Nobleworld.biz website: http://www.nobleworld.biz/images/Lhermitt e.pdf

Lotman, Y. M. (2000). Universe of the mind: A semiotic theory of culture. London, England: I.B. Tauris.

Lukianova, T., \& Ilchenko, A. (2019). Intersemiotic Translation: Meaning-Making in Film and Musical Art. Cognition, communication, discourse, 19, 78-95. Retrieved from https://periodicals.karazin.ua/cognitiondisco urse/article/view/15067/14045

Matito, F. D. (2019). La deriva hacia la burla en el contexto de las prácticas del teatro barroco español. Hispanofila, 185, 23-37, doi: 10.1353/hsf.2019.0002. 
Peirce, Ch. (1931-1935, 1958). The Collected Papers of C. S. Peirce. Cambridge, MA: Harvard University Press.

Peirce, Ch. (2000). The Beginning of Pragmatism. Saint Petersburg: Laboratory for Metaphysical Research, Faculty of Philosophy Publ.

Perdikaki, K. (2017). Towards a model for the study of film adaptation as intersemiotic translation. The Journal of Specialized Translation. Retrieved from http://www.intralinea.org/specials/article/a model_for_the_study_of_film_adaptation_as _intersemiotic_translation
Pym, A. (1992). Translation and text transfer: An essay on the principles of intercultural communication. Berlin, Germany: Peter Lang $\mathrm{GmbH}$, Internationaler Verlag der Wissenschaften.

The movie database. (2016). Inferno. Retrieved July 14, 2021, from Themoviedb.org website: https://www.themoviedb.org/movie/207932inferno

Wildfeuer, J., \& Bateman, J. A. (2017). Conclusion: Film Text Analysis - A New Beginning? In J. Wildfeuer \& J. A. Bateman (Eds.). Film Text Analysis: New Perspectives on the Analysis of Filmic Meaning (pp. 187-198). New York: Routledge. 